\title{
Relationship between general CSR management practices and the development of internal social responsibility
}




\begin{abstract}
Companies that embrace corporate social responsibility (CSR) tend to adopt certain general practices, such as: establishing social responsibility areas, preparing codes of ethics, publishing social or sustainability reports, joining organizations that promote social responsibility, or starting their own foundations. The question then arises as to whether these general practices actually influence the responsible behavior of companies. This article explores the relationship between the application of these general CSR practices and the level of development of internal social responsibility (ISR). To study this relationship, information was drawn from the system of CSR indicators (CSRI) overseen by the Cristian Association of Business Managers (Asociación Cristiana de Dirigentes de Empresas, a self-evaluation system in which Uruguayan companies participate annually. The CSRI uses 25 indicators to measure the level of ISR development and record the application of eight general CSR practices. After carrying out a review of the literature, the 25 indicators were organized into nine dimensions of ISR: employees' human rights; informing employees about issues that affect them; occupational health and safety; internal environment; personal and professional development; employment protection; voluntary provision of benefits; union relations; and fair pay. After analyzing the statistical correlation between the application of general CSR practices and the level of development of social responsibility across the nine dimensions, the results indicate the following: three general practices positively correlate with the development of ISR in all its dimensions (including CSR in strategic planning, involving the management team in CSR issues, and joining an organization that promotes CSR); one practice (preparing a code of ethics) correlates with half of the dimensions; and the other four practices (publishing a social or sustainability report, assigning a full-time employee to CSR management, having a CSR team or area, and possessing a foundation) correlate with none or almost none of the dimensions.
\end{abstract}

Keywords: Corporate social responsibility, internal social responsibility, general social responsibility practices, externalities, dimensions. 


\section{Introduction}

A growing number of firms around the world have embraced corporate social responsibility (CSR). In general, these firms are characterized for carrying out and disseminating social actions, promoting employee volunteering, implementing development programs for small-scale suppliers, introducing responsible environmental practices to their production processes, encouraging ethical behavior among their staff members, and so on. To support and facilitate these actions, some companies incorporate practices such as aligning their mission and vision statements to a CSR focus, incorporating CSR topics into their strategic planning, placing CSR topics on the agenda of their management teams, applying a code of ethics, publishing social or sustainability reports, and establishing CSR management areas. In the Latin American case companies are members of national organizations (such as IARSE in Argentina, Instituo ETHOS in Brazil, Acción Empresarial in Chile, Corporación FENALCO Solidario in Colombia, Asociación Empresarial para el Desarrollo in Costa Rica, Consorcio Ecuatoriano para la Responsabilidad Social in Ecuador, CEMEFI in Mexico, SUMARSE in Panama, Perú 2121 in Peru, DERES in Uruguay) and international organizations (such as Global Compact Network) that promote, and have brought their corporate foundations (originally geared toward philanthropic activities) into line with their CSR strategies in the communities in which they operate.

In this context, it is worth asking whether these practices do in fact have a positive influence on the responsible behavior of companies. In other words, do these practices translate into concrete actions conducive to responsible management of business externalities vis-a-vis stakeholders and the environment? The answer to this question is important, for various reasons: 1) because these actions require resources, and it is important to determine whether these resources are used efficiently to improve CSR; 2) because, in general, these actions are easy to communicate and can be used by companies as an easy means of projecting an image of social responsibility.

The goal of this article is to address this question, centering on the relations that companies have with their main stakeholders: their employees. Thus, the article studies the relationship between general CSR practices (for example, including CSR in strategic planning, publishing a sustainability report, having a CSR area, etc.) and the actual extent of actions conducive to mitigating negative externalities on employees, and to fostering positive externalities. That is, it seeks to establish whether the presence of these generic components of CSR management actually translate into internal social responsibility (ISR). In so doing, the aims to help answer key questions such as: Does incorporating CSR into a business strategy result in greater development of policies aimed specifically at reducing discrimination, occupational diseases, and workplace accidents? Does having a CSR team equate to more responsible management of layoffs and better promotion of employees' personal and professional development? In sum, this study seeks to verify whether the use of these general practices gives rise to concrete responsible management practices in relation to the different types of externalities on employees.

With regard to the research design, a review of the academic literature and of the bibliography produced by organizations that promote CSR gave rise to two decisions. First, the chosen definition of ISR draws together two strands of thought about CSR: on the one hand, that which equates CSR with the satisfaction of stakeholders' needs and demands (Johnson, 1971; Jones, 1980; Carroll, 1999; Khoury, Rostami \& Turnbull, 1999) and on the other, that which equates CSR to the responsible management of business externalities on stakeholders and the environment (Reder; 1994, Fitch, 1976; Gaete 2010; ISO, 2011). For the definition of ISR, the contributions of Turker (2009a), Ena and Delgado (2012), Polák-Weldon, Baldogh, and Bogdany (2013), and ISO (2011), among others, were taken into account. The second decision was to classify the wide spectrum of CSR practices found in the literature into nine dimensions. These dimensions are:1) employees' human rights; 2) informing employees about issues that affect them; 3) occupational 
health and safety; 4) internal environment; 5) personal and professional development; 6) employment protection; 7) voluntary provision of benefits; 8) union relations; and 9) fair pay.

By way of reference, the study employs the system of CSR indicators (CSRI) overseen by the Cristian Association of Business Managers (Asociación Cristiana de Dirigentes de Empresas, ACDE) in Uruguay. ${ }^{1}$ The CSRI is a CSR self-assessment tool based on a self-administered questionnaire, completed every year by companies that are actively incorporating CSR into their management. The present study utilizes information contributed in 2019 by 42 companies across 25 ISR indicators and eight general CSR management practices: incorporating CSR into strategic planning, involving the management team in CSR issues, publishing a sustainability report, having a code of ethics, having a CSR area, appointing a full-time employee to oversee CSR, being a member of an organization dedicated to CSR promotion, and possessing a foundation.

The statistical analysis of the data demonstrates that three of these general practices correlate positively with a greater level of execution of CSR management. These are: incorporating CSR into the company's overall strategy; involving the management team in CSR issues; and being a member of an organization dedicated to CSR promotion, It was also found that having a code of ethics and publishing a sustainability or social report is positively correlated with CSR management. On the other hand, the data did not validate the existence of correlation in the case of the three remaining general practices: having a team to coordinate CSR issues, appointing a full-time employee to oversee CSR, and possessing a foundation. These results contribute to a better understanding of the relationship between these general CSR practices and ISR management processes. They suggest that certain common general practices of companies--which often form the basis of public opinion about their socially responsible behavior--do not create any actual impact on ISR, while other practices do. These results contribute to an improved understanding of the most effective strategies for implementing CSR and ISR, while questioning the validity of certain commonly used indicators to qualify companies as socially responsible.

\section{Theoretical framework}

\section{The concepts of corporate and internal social responsibility}

The concept of corporate social responsibility has been evolving since Brown (1950) published his book about the social responsibility of entrepreneurs, as various studies attest (Carroll, 1999; Garriga \& Melé, 2004; Dahlsrud, 2008; James, 2012; Carroll, 2015; Licandro, Alvarado-Peña, Sansores, \& Navarrete, 2019). This has impacted the way in which academics have approached the application of CSR to the relationship between companies and their employees. This evolution can be broken down into at least three stages. In the first stage, CSR was largely limited to the responsibility of companies to the society in which they operate, which brought it in line with the concept of corporate citizenship. The idea was that, as well as economic, moral, and legal responsibilities, companies could voluntarily assume responsibilities termed "social" (Steiner, 1971; Kok, Van der Wiele, McKenna \& Brown, 2001; Lichtenstein, Drumwright \& Braig, 2004) or "philanthropic" (Carroll, 1991). In general, the voluntary adoption of these responsibilities was founded on instrumental objectives, such as strengthening business reputation or obtaining a license to operate (Murray \& Montanari, 1986; Porter \& Kramer, 2006). Under this approach, CSR was understood as a corporate behavior in parallel to the business operations and aimed at actors outside it--primarily, community institutions (as beneficiaries of CSR) and consumers (as the public among which the company's reputation is to be strengthened through CSR). Thus, according to this perspective, CSR and the human resource (HR) management had nothing in common.

The second stage is a direct consequence of the widespread acceptance of stakeholder theory, proposed by Edward Freeman (1983). This theory prompted a reformulation of the concept of

\footnotetext{
${ }^{1}$ www.acde.org.uy
} 
CSR, expanding its scope to the relationship between the company and its stakeholders as a whole. Carroll (1999) argued that there is a natural coincidence between the concepts of CSR and stakeholder. Kohury, Rostami, and Turnbull (1999) contended that CSR refers to the overall relationship between the company and all its stakeholders. Along the same lines, Garriga and Melé (2004, p.62) proposed that CSR "requires simultaneous attention to the legitimate interests of all appropriate stakeholders and has to balance such a multiplicity of interests and not only the interests of the firm's stockholders." Johnson (1971) had asserted some years earlier that the socially responsible company balances the interests of multiple actors, including employees, suppliers, and local communities. Jones (1980) associated CSR with the idea that corporations have responsibilities toward their employees that go beyond the provisions of union contracts. It was in the framework of this new interpretation of the concept of CSR that its relationship with HR management began to be thought of and studied (Perrini, 2005). It was also under this approach that the concept of internal social responsibility was coined, the first definitions of which were associated with a consideration of employees' rights, needs, and expectations.

The third stage came in the 21 st century, when CSR began to be conceptualized from a new perspective that, in a certain way, encompassed the two previous stages. From this point, CSR came to refer to the management of the impacts or externalities that a company has on its stakeholders, society, and the environment. The antecedents to this conceptualization included Davis and Blomstronm (1966), who had proposed that CSR means the obligation to consider the effects of business decisions and actions on the entire social system. Similarly, some years later, Fitch (1976, p.38) defined it as "the serious attempt to solve social problems caused wholly or in part by the corporation." Subsequently, Frederick, Post and Davies (1992) interpreted CSR as the principle that companies must take responsibility for the effects of any of their actions on the community and the environment, Carroll (2015) observed that socially responsible management of impacts contain two dimensions: on the one hand, protecting society from negative impacts; and on the other, contributing to improving societal conditions through deliberately pursued positive impacts. The definition of social responsibility proposed in the ISO 26000 "Guidance on Social Responsibility" pertains to this current of thought. Its definition of the concept is very clear: "responsibility of an organization for the impacts of its decisions and activities [products, services, and processes] on society and the environment [...]" (ISO, 2011, p.106).

From this new perspective, the concept of CSR extends the spectrum of companies' responsibilities towards their employees. It was no longer a question of satisfying the needs and expectations not covered by labor legislation and employment contracts (that is, of generating positive externalities), but of minimizing the negative externalities of their decisions and actions. Reder (1994) was one of the first authors to propose that CSR include responsibility for internal impacts on the workforce. In the case of Latin America, Gaete (2010, p.43) argued that companies "should pay special attention to attenuating behavior that are related to socially irresponsible forms of expression" (translation ours) with reference to certain negative externalities: labor instability, low income, absence of training or a career, poor working environment, high rates of stress, occupational accidents, and discrimination. The ISO 26000 standard proposes a classification of impacts across seven categories, which it calls core subjects, one of which is labor practices. This subjects contain guidance on ISR that is organized in turn into five subcategories, or issues. These issues include negative impacts that ought to be avoided or minimized (for example, reducing occupational diseases, mitigating the negative effects of dismissals, facilitating a work--life balance, etc.) as well as positive impacts that are to be pursued (for example, promoting employees' personal development, providing support to employees with addictions, etc.).

In the literature, there is no indication of a discernible theoretical drive to propose or argue for a definition of ISR or of socially responsible management of employees. Indeed, Buciuniene and Kazlauskaite (2012, p.4) observed that there is no comprehensive definition of responsible human resources and that "research has only offered some HRM [human resource management] practices that socially responsible organizations tend to follow or are at least expected to follow." Moreover, few authors have proposed a general definition of ISR. Ena and Delgado (2012, p. 58) 
defined it as "the part of corporate social responsibility that manages the human resources of a company socially, ethically, humanistically, and supportively (translation ours); Ferreira and Real de Oliveira (2014, p.234) associated CSR with CSR practices "that are directly related with the physical and psychological labor environment of employees" (translation ours); Obeidat (2016, p365) noted that "internal corporate social responsibility is related to all the company's internal operations" (translation ours); and Ofenhejm and Queiroz (2019, p.355) propose that "sustainable work systems presume that management of work systems go beyond behaviorable and economic aspects, since minimizing human, social, and environmental harm inflicted on these relations becomes a responsibility for companies" (translation ours). In much of the literature there is an abundance of "extensional" definitions--that is, definitions based on the enumeration of practices, dimensions, or thematic areas that involve the concept of ISR (Enhert, 2006; Jaramillo, 2011; Barrena-Martínez et al., 2017).

\section{The dimensions of internal social responsibility}

The review of the literature on ISR indicates that: a) there is a long list of ISR practices; b) these practices are organized into different dimensions or thematic areas; and c) there is no agreement on the best classification of ISR dimensions. Tables 1 and 2 attest to these affirmations. They present the ISR dimensions or practices identified in six institutional publications (Table 1) and fifteen academic publications (Table 2). Three of the institutional publications are documents widely used internationally (GRI, ISO 2.000, and SA 8000), while the other three correspond to institutions that promote CSR in Latin America. As such, it was decided to organize ISR practices into nine dimensions, as outlined after Table 1.

Table 1 Thematic areas of ISR included in institutional publications

\begin{tabular}{|c|c|}
\hline Sources & Thematic areas \\
\hline $\begin{array}{c}\text { DERES (2001) } \\
\text { Uruguay }\end{array}$ & $\begin{array}{l}\text { a) Diversity, equal opportunities, and cohabitation; b) communication and } \\
\text { participation; c) empowerment; d) training and professional development; e) } \\
\text { retirements and terminations; f) work--family balance; g) promotion of a healthy } \\
\text { life. }\end{array}$ \\
\hline $\begin{array}{c}\text { IARSE (2005) } \\
\text { Argentina }\end{array}$ & $\begin{array}{l}\text { a) Diversity; b) sexual harassment; c) training, coaching, and personal development; } \\
\text { d) delegation of authority; e) pay and incentives; f) downsizing and redundancies; } \\
\text { g) work--family balance; h) health, safety, and wellbeing. }\end{array}$ \\
\hline $\begin{array}{l}\text { Global Reporting } \\
\text { Initiative (2006) }\end{array}$ & $\begin{array}{l}\text { a) Employment; b) labor/management relations; c) occupational health and safety; } \\
\text { d) training and education; e) diversity and equal opportunity. }\end{array}$ \\
\hline $\begin{array}{c}\text { SA } 8000 \\
\text { Social } \\
\text { Accountability } \\
\text { International } \\
(2008)\end{array}$ & $\begin{array}{l}\text { a) Child labor; b) forced labor; c) health and safety at work; d) freedom of } \\
\text { association and right to collective bargaining; e) discrimination; f) disciplinary } \\
\text { measures; g) working hours; h) pay; i) management systems. }\end{array}$ \\
\hline $\begin{array}{l}\text { ISO } 26000 \\
\text { ISO }(2011)\end{array}$ & $\begin{array}{l}\text { a) Employment and employment relationships; b) conditions of work and social } \\
\text { protection; c) social dialogue; d) health and safety at work; e) human development } \\
\text { and training in the workplace. }\end{array}$ \\
\hline $\begin{array}{c}\text { Ethos (2007) } \\
\text { Brazil }\end{array}$ & $\begin{array}{l}\text { a) Dialogue and participation (relationship with unions, participatory management); } \\
\text { b) respect for the individual (placing value on diversity, non-discrimination, racial } \\
\text { equity, gender equity, outsourced workers, and child development); c) decent work } \\
\text { (pay, benefits, career, health, safety, working conditions, layoffs, retirement). }\end{array}$ \\
\hline
\end{tabular}

Human rights. The publications refer to practices related to: diversity (Albinger \& Freeman; 2000; DERES, 2001; IARSE, 2005; GRI, 2006; Fenwick \& Bierema, 2008; Gaete, 2010; ETHOS, 2007; García \& Duque, 2012), minorities (Albinger \& Freeman, 2000), gender equity (Albinger \& Freeman, 2000; ETHOS, 2007; Duarte \& Neves, 2011), racial equity (ETHOS, 2007), inclusion of vulnerable or special needs groups (De Paula, Da Silva, \& Tscha, 2011), equal opportunities (DERES, 2001; Perrini, 2005; GRI, 2006; Turker, 2009b; Gaete, 2010), 
discrimination (Social Accountability International, 2008; ETHOS, 2007; Jaramillo, 2011), harassment (IARSE, 2005; Gaete, 2010), child labor (Social Accountability International, 2008; ETHOS, 2007; Jaramillo, 2011; López, Ojeda, \& Ríos, 2016), forced labor (Social Accountability International, 2008; López et al., 2016), respect for human dignity (Jaramillo, 2011), as well as general references to human rights (Guzmán, 2016; López et al., 2016).

Informing employees about issues that affect them. This dimension includes practices related to raising employee awareness of their rights (De Paula et al., 2011; López et al., 2016), providing employees with information on CSR practices (López et al., 2016), applying transparency (De Paula et al., 2011; Barrena-Martínez, López, \& Romero, 2017) and dialoguing with and receiving initiatives from employees (Sánchez Hernandez, Gallardo-Vazquez, Barcik, \& Dziwinski, 2016).

Occupational health and safety. This is a dimension that is prevalent in the literature, couched in this or similar terms (Perrini, 2005; IARSE, 2005; GRI, 2006; Alves \& Mundin, 2008; Social Accountability International, 2008; ETHOS, 2007, ISO, 2011; García, Azuero, \& Peláez, 2013 ; Sánchez Hernandez et al., 2016), but also in references to wellbeing (IARSE, 2005; Buciuniene \& Kazlauskaite, 2012), to the work environment (Turker, 2009b), to hygiene in the workplace (Gaete, 2010 ) and to the promotion of a healthy life (DERES, 2001).

Internal environment. This dimension includes a set of practices that foster the creation of a positive internal environment and, thus, render work a pleasant activity that generates satisfaction and happiness in people. Of these practices, the most salient are management of the organizational climate (Guzmán, 2016), employee participation and empowerment (Albinger \& Freeman, 2000; DERES, 2001; Alves \& Mundim, 2008, ETHOS, 2007; Gaete, 2010; García \& Duque, 2012), promotion of healthy coexistence and integration (DERES, 2001; Gaete, 2010); internal communications (Perrini, 2005; Buciuniene \& Kazlauskaite, 2012) and ensuring staff satisfaction (Perrini, 2005).

Promoting personal and professional development. This dimension groups together the following actions that contribute to the comprehensive development of the worker as a person: training and education (DERES, 2001; Perrini, 2005; GRI, 2006; Turker, 2009b; ISO, 2011; Jaramillo, 2011; Sánchez Hernandez et al., 2016; Barrena-Martínez et al., 2017), professional development (DERES , 2001; Alves \& Mundim, 2008; ETHOS, 2007; Jaramillo, 2011; Buciuniene \& Kazlauskaite, 2012; García, Azuero, \& Peláez, 2013), personal and human development (IARSE, 2005), balance between work life and personal--family life (DERES, 2001; IARSE, 2005; Turker, 2009b; Gaete, 2010; Duarte \& Neves, 2011; Jaramillo, 2011; Guzmán, 2016; Sánchez Hernandez et al., 2016) and promotion of employee volunteering (Sánchez Hernandez et al., 2016).

Employment protection. This dimension refers to the set of practices related to the protection of employment and responsible management of terminations. It covers policies and actions related to job creation (Sánchez Hernandez et al., 2016), downsizing (IARSE, 2005), job stability (Gaete, 2010; Jaramillo, 2011), responsible management of layoffs ( DERES, 2001; IARSE, 2005, Alves \& Mundim, 2008; ETHOS, 2007; De Paula et al., 2011; García \& Duque, 2012; García, Azuero \& Peláez, 2013;) and retirement (DERES, 2001 ; ETHOS, 2007; De Paula et al., 2011; García \& Duque, 2012; García, Azuero \& Peláez, 2013)

Union relations. Union relations refer to actions that contribute to the better exercise of union rights and the building of employer--union relations. These actions include relations with unions in general (Albinger \& Freeman, 2000, Alves \& Mundim, 2008; García \& Duque, 2012; García, Azuero \& Peláez, 2013; Barrena-Martínez et al., 2017), collective bargaining (Social Accountability International, 2008; ISO, 2011), social dialogue (ISO, 2011; Jaramillo, 2011) and respect for labor union rights (Social Accountability International, 2008). 
Voluntary provision of benefits. Included within this dimension are actions related to fringe benefits, disbursed voluntarily in addition to salary (Perrini, 2005; ETHOS, 2007; Jaramillo, 2011; Barrena-Martínez et al., 2017), programs that address the needs of employees' families (Albinger \& Freeman, 2000; García \& Duque, 2012; García, Azuero, \& Peláez, 2013) and programs that support employees in addressing personal problems (addictions, psychological problems, etc.).

Fair pay. This dimension encompasses a general reference to remuneration policies (IARSE, 2005; Social Accountability International, 2008; Alves \& Mundim, 2008; Gaete, 2010; Sánchez Hernandez et al., 2016) and, more specifically, to fair and equitable remuneration (Jaramillo, 2011; López et al., 2016), to decent pay (ETHOS, 2007) and to reasonable pay (Turker, 2009b). Also included here are practices related to profit-sharing (Buciuniene \& Kazlauskaite, 2012; García \& Duque, 2012).

Table 2 Thematic areas of ISR included in academic publications

\begin{tabular}{|c|c|}
\hline Sources & Thematic areas \\
\hline $\begin{array}{c}\text { Albinger \& } \\
\text { Freeman }(2000)\end{array}$ & $\begin{array}{l}\text { a) Diversity (representation of women and minorities, benefits and family programs; } \\
\text { b) labor issues (union relations, benefits and employee participation). }\end{array}$ \\
\hline Perrini (2005) & $\begin{array}{l}\text { a) Staff composition ; b) rotation; c) equal treatment; d) training; e) working hours; } \\
\text { f) salary structures; g) absence from work; h) employee benefits; i) labor relations; } \\
\text { j) internal communications; k) health and safety; l) staff satisfaction; m) workers' } \\
\text { rights. }\end{array}$ \\
\hline $\begin{array}{c}\text { Fenwick \& } \\
\text { Bierema }(2008)\end{array}$ & $\begin{array}{l}\text { Through interviews, HR managers were found to associate ISR with the following: } \\
\text { "certain CSR themes were evident in HRD practices reported by managers: } \\
\text { emphases on learning, ethics, staff wellness and well-being, employees' control of } \\
\text { learning, respect, diversity and responsibility." (p.31) }\end{array}$ \\
\hline $\begin{array}{l}\text { Alves \& Mundim } \\
\quad(2008)\end{array}$ & $\begin{array}{l}\text { Participatory management; b) relations with labor unions; c) remuneration policy; } \\
\text { d) benefits and career; e) healthcare; f) safety and working conditions; g) } \\
\text { commitment to professional development; h) behavior in response to dismissals. }\end{array}$ \\
\hline Turker (2009b) & $\begin{array}{l}\text { a) Benefits to improve employees' quality of life ; b) reasonable pay; c) safe and } \\
\text { healthy work environment; d) support of employee education and skills } \\
\text { development ; e) balance between work and family life; f) fair administrative } \\
\text { decisions; g) equal opportunities. }\end{array}$ \\
\hline Gaete (2010) & $\begin{array}{l}\text { a) Equal opportunities; b) diversity management; c) prevention of moral } \\
\text { harassment; d) reconciliation of family and work life; d) the right to be well } \\
\text { managed; e) health and safety at work; f) job design; g) remuneration, promotion, } \\
\text { and job security; h) integration and participation; i) social relevance of the work } \\
\text { activity. }\end{array}$ \\
\hline $\begin{array}{l}\text { De Paula, Da } \\
\text { Silva, \& Tscha } \\
\quad(2011)\end{array}$ & $\begin{array}{l}\text { a) Add (e.g. favor the inclusion of groups with special needs, guarantee transparency } \\
\text { in the recruitment process; b) reward (e.g. have clear rules for professional mobility, } \\
\text { ensure pay is compatible with market levels); c) develop (e.g. raise awareness about } \\
\text { employee rights, provide quality of life programs); d) terminate (e.g. prepare the } \\
\text { employee for retirement, support outplacement in dismissal processes); and others } \\
\text { (e.g. devise codes of ethics, guarantee the quality of life of employees). }\end{array}$ \\
\hline Jaramillo (2011) & $\begin{array}{l}\text { "These initiatives are aimed fundamentally at preserving the labor rights of } \\
\text { workers, which includes responsible and ethical hiring practices; fair and equitable } \\
\text { remuneration, social benefits; healthcare, social, and workplace protection and } \\
\text { security; commitment to personal, professional, and occupational development, } \\
\text { training, and lifelong learning; stability and employability; freedom of association } \\
\text { and social dialogue; elimination of all types of child labor, exploitation, and } \\
\text { discrimination; right to equity, diversity, and respect for human dignity; the } \\
\text { balance between family and work life; and ultimately at improvements in the } \\
\text { quality of life at work, greater harmony, and the optimization of the win-win } \\
\text { relationship between the company and its internal stakeholders"(page 178; } \\
\text { translation ours). }\end{array}$ \\
\hline
\end{tabular}


Buciuniene \& The analysis of human resource management practices related to CSR included the Kazlauskaite following: 1) Profit sharing and shared ownership schemes; 2) employee health and (2012). Wellbeing; 3) responsible recruitment; 4) responsible training; 5) responsible career progression; 6) flexible working arrangements; 7) communication to employees; 8) communication from employees.

García \& Duque

(2012)

a) Respect for the individual, equity, and diversity; b) employee involvement in company management c) relations with unions and organized employee groups; d) distribution of company profits; e) professional development and employability; f) healthcare, safety, and working conditions; g) retirement and layoffs; h) families of employees.

\begin{tabular}{|c|c|}
\hline $\begin{array}{l}\text { García, Azuero, } \\
\text { \& Peláez (2013) }\end{array}$ & $\begin{array}{l}\text { Respect for the individual, equity and diversity; b) employee involvement in } \\
\text { company management c) relations with unions and organized employee groups; d) } \\
\text { distribution of company profits; e) professional development and employability; f) } \\
\text { healthcare, safety, and working conditions; g) retirement and layoffs; h) families of } \\
\text { employees. }\end{array}$ \\
\hline Guzmán (2016) & $\begin{array}{l}\text { Human rights; b) health and safety; c) labor relations; d) work--family--leisure } \\
\text { balance; e) organizational climate; f) quality of life. }\end{array}$ \\
\hline $\begin{array}{l}\text { López, Ojeda \& } \\
\text { Ríos (2016) }\end{array}$ & $\begin{array}{l}\text { Fair and satisfactory pay; b) prohibition of forced and child labor; c) application of } \\
\text { and respect for human rights; d) safe and healthy working conditions; e) hours of } \\
\text { work and rest; f) working environment free from moral and sexual harassment; g) } \\
\text { respect for labor practices; h) code of ethics to guide employees; i) policies to } \\
\text { penalize acts of corruption; j) providing information on CSR to employees. }\end{array}$ \\
\hline $\begin{array}{c}\text { Sánchez- } \\
\text { Hernández, } \\
\text { Gallardo- } \\
\text { Vázquez, Barcik, } \\
\text { \& Dziwinski } \\
\text { (2016) }\end{array}$ & $\begin{array}{l}\text { a) Job creation and inclusion through employment; b) wages and compensation; c) } \\
\text { dialogue about and reception of employee initiatives; d) occupational health and } \\
\text { safety; e) employee training and development; f) reconciliation between family and } \\
\text { work life; g) equal opportunities; h) pensions; i) promotion of volunteering; j) } \\
\text { raising awareness about CSR. }\end{array}$ \\
\hline $\begin{array}{l}\text { Barrena- } \\
\text { Martínez, López, } \\
\text { \& Romero } \\
\text { (2017) }\end{array}$ & $\begin{array}{l}\text { a) Employee attraction and retention; b) training and continuous development; c) } \\
\text { management of labor relations; d) communication, transparency, and social } \\
\text { dialogue; e) diversity and equal opportunities; f) fair pay and social benefits; g) } \\
\text { health and safety at work; h) work--family balance. }\end{array}$ \\
\hline
\end{tabular}

Source: compiled by authors.

\section{General practices related to corporate social responsibility management.}

Companies that embrace CSR adopt different practices for its management. Some of these practices are strategic, such as adapting the mission and vision statements to the CSR approach, incorporating CSR topics into strategic planning, and including CSR in the senior management agenda. Other practices involve changes to the structure and the responsibilities of the various company areas:, such as creating CSR management areas, organizing cross-cutting CSR teams peopled by representatives of key company areas, assigning specific CSR responsibilities to the managers of each area, etc. Another group of practices relates to the publication of documents that have some kind of CSR function. The best known practices are the publication of codes of ethics and social or sustainability reports. It is also possible to include, within these practices, the use of corporate foundations to direct CSR actions toward the community and membership of national and international organizations whose mission is to promote CSR. Each of them plays a role in the application of CSR.

CSR and strategic planning. Various authors have pointed to the need for companies to incorporate CSR into their general strategy so as to ensure its application across the entire operation. This is all the more true of HR strategy, in which ISR objectives can be included. Sarmiento del Valle (2010) noted that the application of CSR cannot be left to chance, and that strategic management is required. Godiwalla (2012, p.4) observed that social responsibility 
processes are "important and integral parts of strategic management." In the same vein, Fernandez-Gago and Martínez-Campillo (2008) contended that the application of social responsibility concerns the attainment of strategic objectives. For their part, Gracias and Melendez (2019, p.7) indicated that "strategic planning contributes to efficient management for the fulfillment of CSR programs" (translation ours). Murray and Vogel (1997) argued that effective management of a good CSR strategy requires identification of the stakeholders, development of action strategies for the target groups, and measurement of the programs' effectiveness. Focusing specifically on the application of CSR to developing brand image, Alzate and Orozco-Toro (2015) proposed that CSR should be a component of branding strategies. Likewise, several studies have stressed the strategic role of CSR in achieving HR objectives (Zaman \& Nadeem, 2019), and that ISR policies therefore belong to the strategic level. These strategic objectives include attracting talent, demonstrating commitment to employees, and promoting identification with the company. On the other hand, Porter and Kramer (2006) asserted that the predominant CSR approaches are fragmented and disconnected from business and strategy, with the result that "the most common corporate response has been neither strategic nor operational but cosmetic" (Porter \& Kramer, 2006, pp. 2-3). The present study aims to prove the following hypothesis:

Hypothesis 1: A company's incorporation of CSR into its general strategy is associated with a greater level of development of ISR.

The role of senior management in CSR. Some publications have explained the role of leadership in the application of CSR. Kao and Guarneri (2008) stressed the importance of business leaders to CSR as those who take the initiative, live by its values, and communicate its importance. According to Murray and Vogel (1997), CSR requires that business leaders have the inclination to respond to the social environment. In turn, Lee, Yu, Sirgy and Singhapakdi (2018) proposed that the institutionalization of ethics--an essential component for CSR--requires the commitment of senior management because cultural change is inherent to the process. Sarmiento del Valle (2010, p.36) found that "social responsibility is a commitment of all members of a company, the result of management that requires strategies designed, led, and monitored by the leaders" (translation ours). For his part, Bohem (2002, p.172) concluded that corporate leaders favor CSR because it is they who create opportunities to move in new directions and who facilitate change, and thus they use the organization's resources to achieve their aims. In their study, Waldman, Siegel, and Javida (2004) found that certain aspects of transformational leadership are positively correlated with the propensity of companies to participate in CSR, and that leaders of this type are those who will apply CSR strategically. Meanwhile, McWilliams, Siegel, and Wright (2006, p.7) observed that "certain aspects of CEO leadership can affect the propensity of firms to engage in CSR." If CSR is interpreted as the responsible management of company externalities on stakeholders and the environment, it is easy to infer that its application depends on the leadership and involvement of senior and middle managers, and that each of them is responsible for managing one externality or another. Therefore, the inclusion of CSR topics on the agenda of all members of senior management and the creation of cross-cutting teams to lead CSR seems a necessary condition for the application of these policies across all areas of a company. In addition to Hypothesis 1, this study explores the following hypotheses:

Hypothesis 2: The involvement of the management team in CSR issues is associated with a greater level of development of ISR.

Hypothesis 3: Having a team or area tasked with coordinating CSR issues is associated with a greater level of development of ISR.

Hypothesis 4: Appointing a full-time CSR manager is associated with a greater level of development of ISR.

Codes of ethics and CSR. The relationship between ethics and CSR has featured in publications about CSR for several decades (McGuire, 1963; Davis, 1967; Zenisck, 1979; Epstein, 1987; Carroll, 1991). Davis (1967) stated that concern for the ethical consequences of corporate 
behavior is an essential element of CSR. Zenisek (1979) interpreted CSR as a relationship between business ethics and the expectations of society. For Hopkings (1998), CSR was related to ethical treatment of stakeholders. Epstein (1987) pointed out that social responsibility and ethics approach issues and concerns that are closely related and even overlapping. Joyner and Payne (2002) went further, arguing that the terms "ethics" and "CSR" are interchangeable. The adoption of ethical behavior is one of the seven principles on which the concept of CSR as proposed in the ISO 26000 standard (ISO, 2011) is based, and one of the main inputs that, according to this guide, is required to manage externalities in a responsible manner. Since codes of ethics are one of the main tools that companies have for providing ethical orientation, several authors have studied their relationship with CSR (Malhotra \& Miller, 1999; Logsdon \& Wood, 2005; Painter-Morland, 2006; Valentine \& Fleischman (2008); Calderón, Ferrero, \& Redín, 2012; Rudnika, 2017).

ISO 26000 indicated that companies can promote social responsibility by "adopting written codes of conduct or ethics that specify the organization's commitment to social responsibility by translating the principles and values into statements on appropriate behaviour" (ISO, 2011, p.126). In turn, Lee, Yu, Sirgy and Singhapakdi $(2012, \mathrm{p}, 856)$ pointed out that codes of ethics "influence manager's perception of ethical problems and the perception of remedial alternatives" while also having a "significant influence on perceived importance of ethics and social responsibility." Logsdon and Wood (2005) contented that global corporate citizenship, proposed in preference to CSS, is based on four pillars--one of which is corporate values, which must be explained in a code of conduct. For these authors, a code of conduct should be, above all, "a clear expression of the core values and principles the company upholds throughout all its locations and transactions" (Logsdon \& Wood, 2005, p.58). It is worth noting that some companies, such as the multinational Kimberly-Clark (DERES, 2015), insist that their suppliers adopt the standards contained in their codes of conduct. In this regard, Rudnika (2017, p.93) pointed out that these codes "are tools that socially responsible organizations use to implement norms, principles and rules that they expect from their suppliers." But despite these ideas, studies on the relationship between codes of ethics and the application of CSR have not yielded conclusive results. Valentine and Fleischman (2008) observed that the existence of codes of ethics, and their adequate communication, has a positive impact on the CSR perceived by employees. Based on this finding, the authors concluded that "codes and ethics training might be used to enhance organizational approaches that emphasize CSR" (Valetine \& Fleschman, 2008, p.166). In like manner, Vittel, Paolillo and Thomas (2003) detected a positive correlation between the existence of a code of ethics and the importance that employees place on CSR. However, the study conducted by Calderón et al. (2012, p.1) "provides empirical support for the idea that the philosophy of corporate social responsibility (CSR) is scarcely present in the codes of the most reputable companies." The present study will now turn to its next hypothesis:

Hypothesis 5: Having a code of ethics is associated with a greater level of development of ISR.

CSR and social or sustainability reports. These reports began to be published in the late 1980s. By the end of the 2000s, the number of reports published had increased significantly (Kolk, 2004), such that their study has become a field of research of growing relevance (Isenmann, Bey, \& Welter, 2007). That said, the profuse academic output on sustainability reports has not extended to the relationship between the publication of reports and the actual development of CSR. This output has centered on a wide range of topics, most notably: descriptive studies of different countries and sectors (Gallego, 2005; Furtotti, Mazza, Tibiletti, \& Triani, 2017, Clemente et al., 2019; Berniak-Woźny \& Kawasek, 2020), the problem of verification of the information contained in these documents (Hussey, Kirsop, \& Meissen, 2001; Simnett, Vanstraelen, \& Chua, 2009; Manetti \& Becati, 2009; Boiral, Heras Saizarbitoria, Brotherton, \& Bernard 2019), the reasons why companies publish them (Delfgaauw, 2000; Morhardt, Baird, \& Freeman, 2002; Willis, 2003), the tools and metrics companies use in their preparation (Wallage, 2000; Hussey, Kirsop \& Meissen, 2001; Willis, 2003; Isenmann et al. 2007; Marinescu, 2020), the readability of reports (Nilipour, De Silva, \& Xuedong, 2020; Smeuninx, De Clerck \& Aerts, 2020), the role 
of stakeholders in their preparation and communication (Johansen, 2010; Manetti, 2011; Fernndez-Feijoo et al., 2014;) and the degree of compliance with standards (Marinescu, 2020). Although descriptive studies and those that analyze compliance with standards provide information about the level of CSR development of companies that publish reports, they do not use information to assess whether these companies are more advanced in terms of CSR than those that do not publish such reports. This leads the present study to the following hypothesis:

Hypothesis 6: Periodically publishing a social or sustainability report is associated with a greater level of development of ISR.

Foundations and CSR. Corporate foundations are non-profit institutions (Achtenhagen, Melesko, \& Ots, 2018), created and financed by companies (Westhues \& Einwiller, 2006) but independent from them (Thomsen, Poulsen, Børsting \& Kuhn, 2018). Although these foundations emerged as instruments to channel funds toward corporate philanthropy (Bereskin \& Hsu, 2016), many companies have expanded their mission to transform these foundations into wings for the execution of CSR strategies targeted at the local community. This change is explained by a combination of factors, outstanding among which are the gradual substitution of the corporate citizenship approach with a broader CSR approach, and the emerging tendency to link social investments with the business strategy. This has rendered corporate foundations important actors within the CSR strategies of the companies behind them (Herlin \& Pedersen, 2012; Minciullo \& Pedrini, 2015), as demonstrated by the range of activities carried out by the foundations of major multinational companies, such as Fundación Prosegur, Fundación Telefónica, Ronald McDonald House Charities, and Fundación ITAÚ Social. In some countries, it has been observed that the rise in the number of corporate foundations is explained by the growing importance of CSR (Westhues \& Einwiller, 2006).

Despite this new role, studies on corporate foundations are thin on the ground (Minciullo \& Pedrini, 2015); in particular, there is "little to no research targeting the influence of corporate foundations on their founding companies' implementation of CSR activities" (Herlin \& Pedersen, 2012, p.59). The few studies that there are on corporate foundations have found that these institutions make certain contributions to their parent companies' application of CSR: a) they become active promoters of CSR within these companies (Herlin \& Pedersen, 2012); b) they generate positive effects on corporate values (Bereskin \& Hsu, 2016); c) they act as antennas that detect social expectations and favor dialogue with stakeholders (Westhues \& Einwiller, 2006), particularly employees (Monfort \& Villagra, 2016); d) they serve to publicly demonstrate the social commitment of their parent companies (Westhues \& Einwiller, 2006), and to make a positive impact on their image and credibility (Askeroğlu \& Bajar 2014). The next hypothesis tested in the present study is as follows:

Hypothesis 7: Possessing a foundation or participating alongside other companies in a foundation is associated with a greater level of development of ISR.

In some countries, groups of companies involved in the CSR discourse have come together to form civil associations whose mission is to promote CSR. These non-profit organizations arrange forums and conferences, hold training workshops, draft CSR implementation manuals and guides, disseminate the good practices of their member companies, build self-assessment tools, and so on. Some of them also played a standout role in the preparation of the ISO 26000 standard. Despite the paucity of studies about these organizations, it seems likely that membership will be greater CSR incorporation. Accordingly, the final hypothesis in the present study is:

Hypothesis 8: Membership of organizations dedicated to CSR promotion and training is associated with a greater level of development of ISR.

As noted earlier, the focus of this study is one that has featured little in the literature. One exception is Buciuniene and Kazlauskaite (2012), who explored the relationship between a 
general set of CSR management practices (possessing a CSR statement, a diversity statement, code of ethics, and a corporate values statement) and a several of the ISR performance indicators (profit sharing, employee health and wellbeing, responsible recruitment, training, responsible career path, organizational flexibility, communication with employees, etc.). Buciuniene and Kazlauskaite (2012) were unable to prove a correlation between the application of these general CSR management practices and the performance of companies across most ISR indicators. Another notable study is Collier and Esteban (2007), who analyzed the relationship between, on the one hand, mission statements and codes of ethics (with a CSR approach) and, on the other, employee commitment. These authors concluded that it is "not enough to have mission statements and codes of ethics. It is necessary for ethics to become embedded in the cultural fabric of the business as well as in the hearts and minds of its members" (Collier \& Esteban, 2007, p.30). But the general lack of empirical study around this topic underlines the importance of the present study.

\section{Research Problems and Methodology}

The purpose of this study is to determine whether the adoption of general practices associated with CSR management (for example, including CSR issues in strategic planning, publishing a sustainability report, having a CSR area, etc.) influences the level of development and the extent of ISR actions.

Therefore, the research problem is to find an answer to the following question: Does the presence of generic components of CSR actually translate into higher levels internal social responsibility?

By way of reference, the study employs secondary information: the system of CSR indicators (CSRI) overseen in Uruguay by the Cristian Association of Business Managers (Asociación Cristiana de Dirigentes de Empresas, ACDE). The CSRI is a CSR self-assessment tool based on the application of a self-administered questionnaire, completed annually by a set of companies. These companies constitute a non-probabilistic sample of the universe of firms in Uruguay that are incorporating CSR processes into their management. The questionnaire ${ }^{2}$ included three series of indicators, which covered: a) the profile of the participating companies; b) the application of various general practices (policies and instruments) related to CSR management (has incorporated CSR into its business strategy, has a code of ethics, publishes a social or sustainability report, etc.); c) the extent of actions aimed at responsible management of business externalities on seven groups of stakeholders (shareholders, employees, suppliers, competitors, clients, state, community) and the environment.

In the case of employees, the indicators in the third group referred to externalities such as avoiding discrimination; providing benefits in terms of healthcare, education, or access to housing; recognizing and/or rewarding good performance; giving training on occupational health and safety, etc. In this study, the 25 indicators on management of employee-related externalities were used as dependent variables (Table 4), while the eight general CSR management practices were used as independent variables (see Table 6).

It should be noted that the questionnaire assigned 27 indicators to employee-focused CSR, but two were eliminated because it was decided that, strictly speaking, they do not constitute ISR practices. The two discarded indicators were: "Ensuring that providers of subcontracted personnel comply with labor legislation and respect the rights of their workers" and "Training workers in the values of the company." Each indicator was classified according to the nine ISR dimensions

\footnotetext{
${ }^{2}$ The questionnaire can be downloaded from http://www.acde.org.uy/irse.php. En 2017 el cuestionario fue modificado, razón por la cual no coincide exactamente con el utilizado en esta Tesis.
} 
described in Section 2.2. Just one of these nine dimensions does not have an indicator in the CSRI: "Fair pay." The indicators and dimensions can be seen in Table 4.

The measurement scale assessed the extent to which each company responsibly manages each of these externalities, utilizing an ordinal scale with semantic support comprised of six values. Each of these values represented different situations that demonstrate how a company approaches the management of each externality. These six values are presented in Table 3 . As can be seen, the scale measures the level of development or the extent of ISR across the 25 indicators.

Table 3: semantic support for the scale used to measure ISR

\begin{tabular}{cl}
\hline Value & \\
\hline I & We do not carry out ACTIONS. \\
2 & We carry out ACTIONS in isolation, but they are not integrated into a POLICY. \\
3 & We carry out ACTIONS and are in the process of establishing a POLICY on the matter. \\
4 & We have a POLICY and have started to align our ACTIONS with that policy. \\
5 & We have a POLICY, have disseminated it internally, and aligned it to most of our \\
& actions. \\
6
\end{tabular}
Source: ACDE (2019)

The companies are given around three months to complete the CSRI questionnaire, and must submit the completed questionnaire by the end of November each year. The information utilized in the present study corresponded to the 17th version (2019), in which 42 companies participated. These companies pertain to a wide spectrum of segments: a) $79 \%$ are private companies, $14 \%$ are state-owned, and $7 \%$ are from the social sector; b) $71 \%$ are Uruguayan-owned, $22 \%$ are foreignowned, and $7 \%$ are mixed; c) the vast majority (95\%) are engaged solely in the domestic market; d) $31 \%$ have less than 100 employees, $26 \%$ have between 100 and 500, and $43 \%$ employ more than 500 people; e) they represent a wide range of industries (agri-business, manufacturing, financial services, healthcare, education, transport, and logistics, etc. and f) $60 \%$ are members of DERES, an organization dedicated to promoting CSR by giving companies the tools to manage this responsibility.

\section{Results}

First, Cronbach's alpha was estimated to determine whether the indicators for each dimension could function as a scale. It was found that in almost all cases the Cronbach's alpha values were higher than 0.7 (see penultimate column of Table 4), which is the minimum value required to accept the reliability of a scale. Only the Alpha value for the set of indicators on "benefits that the company provides to its employees" was below this limit: 0.686 . This result may be a reflection of the heterogeneity of the dimension, which includes a wide spectrum of benefits.

Indexes were built to measure each of the dimensions of ISR, for which the mean value was calculated of the indicators that comprise them.

The final column of Table 4 includes the index value recorded for each of them. This column also presents the general index value of ISR, which was calculated as an average of the values recorded across the 25 indicators.

Table 4 shows that the average value is greater than five across the indicators of all dimensions, except for the dimension related to the benefits that companies voluntarily offer their employees. None of these indicators reached a mean value of five, and in some cases they were well below four. This is true of the following indicators: "Providing support to laid-off or out-of-contract workers for their re-entry into the job market" (3.00) and "Offering subcontracted personnel benefits and/or training similar to that enjoyed by company employees" (3.39). 
Taken together, the results presented in Table 4 show that most companies in the sample have policies in place for the responsible management of most of the externalities. Moreover, a considerable number of the companies have qualified with a score of six points Which indicates that these policies are integrated into the strategy. Therefore, it is concluded that the sample is composed of companies that encompass ISR, although they do so to differing extents.

Table 4

ISR indicators organized by dimensions. Mean value and standard deviation

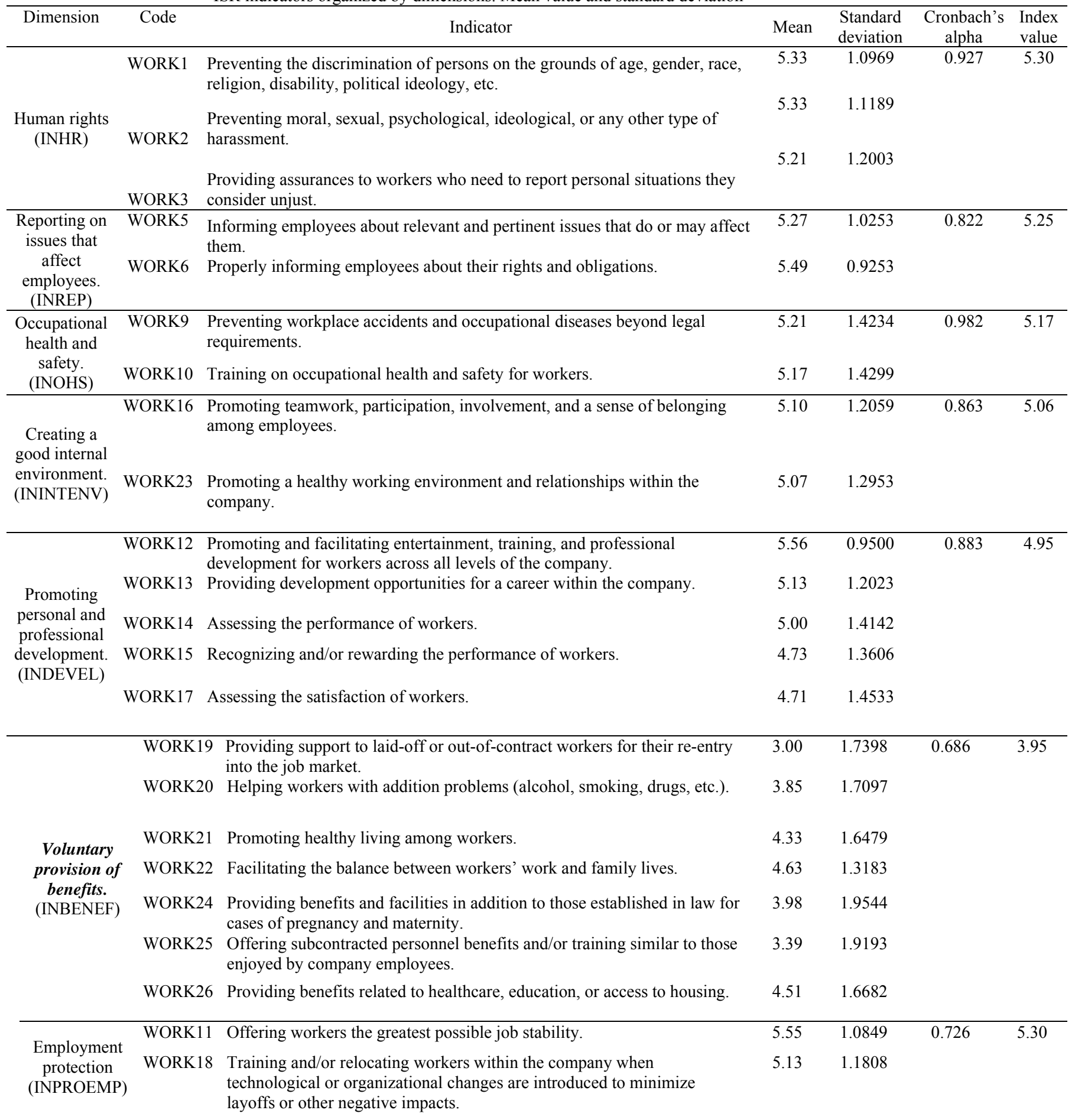


WORK27 Trying to prevent cost reductions by way of layoffs and suspensions. $\quad 5.65 \quad 0.8121$

\begin{tabular}{|c|c|c|c|c|c|c|}
\hline $\begin{array}{c}\text { Union } \\
\text { relations } \\
\text { (INUNREL) }\end{array}$ & WORK8 & $\begin{array}{l}\text { Maintaining good relations and a transparent dialogue with the union that } \\
\text { represents workers. }\end{array}$ & 5.49 & 1.0932 & $\mathrm{~N} / \mathrm{C}$ & 5.49 \\
\hline ISR & IISR & Index that combines the 25 practices. & 5.05 & .96556 & 0.890 & 5.05 \\
\hline
\end{tabular}

Table 5 presents the results of the ANOVA test applied to the indexes of the eight dimensions of ISR. Although literature consider nine dimensions the statistical analysis was made on eight of them. There is no statistical data for the dimension Fair pay. It can be seen that the dimensions are all correlated with one other and that this correlation was strong in all cases, although to a slightly lesser degree for the "benefits" and "union relations" dimensions. This, and the fact that the Cronbach's alpha corresponding to the scale with the 25 indicators was 0.890 (see Table 4), shows that the set of indicators serves to build a reliable scale to measure the level of development of responsible management of externalities on employees; that is, it serves to measure the level of ISR. Table 5 also shows that there was a strong correlation between this scale (INISR) and each of the dimensions that comprise it.

Table 5

ANOVA test between dimensions of ISR

\begin{tabular}{|c|c|c|c|c|c|c|c|c|c|}
\hline & INHR & INREP & INOHS & ININTENV & INDEVEL & INBENEF & IDPROEMP & INUNREL & INISR \\
\hline INHR & I & $.810^{* *}$ & $.773^{* *}$ & $.825^{* *}$ & $.801^{* *}$ & $.499^{* *}$ & $.846^{* *}$ & $.792^{* *}$ & $.907^{* *}$ \\
\hline INREP & $.810^{* *}$ & I & $.605^{* *}$ & $.779^{* *}$ & $.686^{* *}$ & $.479^{* *}$ & $.740^{* *}$ & $.595^{* *}$ & $.803^{* *}$ \\
\hline INOHS & $.773^{* *}$ & $.605^{* *}$ & I & $.715^{* *}$ & $.694^{* *}$ & $.575^{* *}$ & $.685^{* *}$ & $.665^{* *}$ & $.854^{* *}$ \\
\hline ININTENV & $.825^{* *}$ & $.779^{* *}$ & $.715^{* *}$ & I & $.821^{* *}$ & $.495^{* *}$ & $.883^{* *}$ & $.538^{* *}$ & $.885^{* *}$ \\
\hline INDEVEL & $.801^{* *}$ & $.686^{* *}$ & $.694^{* *}$ & $.821^{* *}$ & I & $.567^{* *}$ & $.763^{* *}$ & $.398^{*}$ & $.898^{* *}$ \\
\hline INBENEF & $.499^{* *}$ & $.479^{* *}$ & $.575^{* *}$ & $.495^{* *}$ & $.567^{* *}$ & I & $.361^{*}$ & $.363^{*}$ & $.740^{* *}$ \\
\hline INPROEMP & $.846^{* *}$ & $.740^{* *}$ & $.685^{* *}$ & $.883^{* *}$ & $.763^{* *}$ & $.361^{*}$ & I & $.563^{* *}$ & $.826^{* *}$ \\
\hline INUNREL & $.792^{* *}$ & $.595^{* *}$ & $.665^{* *}$ & $.538^{* *}$ & $.398^{*}$ & $.363^{*}$ & $.563^{* *}$ & I & $.645^{* *}$ \\
\hline INISR & $.907^{* *}$ & $.803^{* *}$ & $.854^{* *}$ & $.885^{* *}$ & $.898^{* *}$ & $.740^{* *}$ & $.826^{* *}$ & $.645^{* *}$ & I \\
\hline
\end{tabular}

**. **The correlation was significant at the 0.01 level (two tails).

*.**The correlation was significant at the 0.05 level (two tails).

Next, the variables that represent the eight general CSR practices were analyzed for possible statistical association. To this end, the Chi-square test was applied given that these are nominal bivariate variables (applicable/not applicable). Table 6 includes the Chi Square value obtained from the test for the relationship between each pair of these variables. There it can be observed that there was no statistical association between these variables as a whole--only for small subsets thereof. These results support the method of formulating and assessing the hypotheses (on the relationship of each of these eight variables with the level of development of ISR) one by one.

Table 6

Chi-squared test applied to the binary relationship between the eight variables of CSR practices and management instruments

\begin{tabular}{clcccccccc}
\hline Code & CSR Management Practices & Man1 & Man2 & Man3 & Man4 & Man5 & Man6 & Man7 & Man8 \\
\hline Man1 & $\begin{array}{l}\text { Includes CSR in strategic } \\
\text { planning. }\end{array}$ & I & 0.131 & $.375^{*}$ & $.459^{* *}$ & 0.157 & $.540^{* *}$ & 0.228 & 0.145 \\
Man2 & $\begin{array}{l}\text { Has a code of ethics or of } \\
\text { conduct. }\end{array}$ & 0.131 & $\mathrm{I}$ & 0.276 & $.364^{*}$ & 0.178 & 0.184 & 0.146 & 0.164 \\
Man3 & $\begin{array}{l}\text { Publishes a social report } \\
\text { (annual or bi-annual). }\end{array}$ & $.375^{*}$ & 0.276 & $\mathrm{I}$ & $.306^{*}$ & 0.175 & 0.133 & 0.266 & 0.129 \\
Man4 & $\begin{array}{l}\text { Has a CSR area or team. } \\
\text { Man }\end{array}$ & $.459^{* *}$ & $.364^{*}$ & $.306^{*}$ & $\mathrm{I}$ & $.343^{*}$ & $.392^{*}$ & 0.24 & 0.045
\end{tabular}




\begin{tabular}{|c|c|c|c|c|c|c|c|c|c|}
\hline Man5 & $\begin{array}{l}\text { Has a full-time employee } \\
\text { dedicated to CSR } \\
\text { management. }\end{array}$ & 0.157 & 0.178 & 0.175 & $.343^{*}$ & I & 0.135 & 0.029 & 0.108 \\
\hline Man6 & $\begin{array}{l}\text { Involves the management } \\
\text { team in CSR issues. }\end{array}$ & $.540 * *$ & 0.184 & 0.133 & $.392 *$ & 0.135 & I & -0.04 & 0.124 \\
\hline Man7 & $\begin{array}{l}\text { Is a member of an } \\
\text { Organization dedicated to } \\
\text { CSR }\end{array}$ & 0.228 & 0.146 & 0.266 & 0.24 & 0.029 & -0.04 & I & 0.239 \\
\hline Man8 & $\begin{array}{l}\text { Possesses a foundation or } \\
\text { participates in a foundation } \\
\text { alongside others. }\end{array}$ & 0.145 & 0.164 & 0.129 & 0.045 & 0.108 & 0.124 & 0.239 & I \\
\hline
\end{tabular}

*The correlation was significant at the 0.05 level (two tails).

**The correlation was significant at the 0.01 level (two tails).

To study the relationship between the application of these practices and the development of ISR, a difference in means test was performed to compare the values recorded across each of the ISR dimensions for companies that apply each practice with those for companies that do not apply each practice.

Table 7 shows the mean values of each segment in each dimension, while Table 8 presents the $\mathrm{F}$ value and the level of significance obtained in the ANOVA test, applied to the mean differences.

Analysis of Hypothesis 1. Across all dimensions of ISR, companies that incorporate CSR in their strategic planning (Man1) posted a much higher value than companies that do not (Table 7).

The differences vary between 2.62 ("reporting on issues that affect employees") and 1.35 ("voluntary provision of benefits)". For all dimensions, the vast majority of companies in the first group integrate policies to responsibly manage employee-related externalities into their strategies. Furthermore, the ANOVA test shows that, in general, this difference was significant. These results indicate that companies that claim to be including CSR in their strategic planning are indeed doing so, at least when it comes to managing externalities on their employees. Therefore, the CSRI data validates Hypothesis 1: A company's incorporation of CSR into its general strategy is associated with a greater level of development of ISR.

Analysis of Hypothesis 2. Again, in this case, the mean values for all dimensions are considerably higher among those companies that answered in the affirmative in the Man6 indicator ("Involves the management team in CSR issues"). The differences range between 2.65 ("union relations") and 0.99 ("voluntary provision of benefits"). The ANOVA test shows that these differences are statistically significant in all cases, except for the "voluntary provision of benefits" dimension. This serves to validate Hypothesis 2: The involvement of the management team in CSR issues is associated with a greater level of development of ISR.

Table 7

Mean value of each dimension of ISR, by application of general CSR management practices

\begin{tabular}{llccccccccc}
\hline & & INHR & INREP & INOHS & ININTENV & INDEVEL & INBENEF & IDPROEMP & INUNREL & IISR \\
\hline Man1 & No & 3.00 & 2.88 & 2.88 & 2.88 & 2.95 & 2.73 & 3.13 & 4.00 & 2.95 \\
& Yes & 5.54 & 5.50 & 5.41 & 5.29 & 5.16 & 4.08 & 5.52 & 5.63 & 5.03 \\
Man2 & No & 4.40 & 4.60 & 3.60 & 4.30 & 4.04 & 3.06 & 4.72 & 5.50 & 3.90 \\
& Yes & 5.42 & 5.34 & 5.38 & 5.16 & 5.08 & 4.07 & 5.37 & 5.48 & 4.96 \\
Man3 & No & 4.95 & 4.89 & 4.50 & 4.78 & 4.60 & 3.72 & 5.03 & 5.17 & 4.49 \\
& Yes & 5.56 & 5.52 & 5.67 & 5.27 & 5.22 & 4.12 & 5.50 & 5.67 & 5.09 \\
Man4 & No & 4.93 & 4.64 & 4.82 & 4.79 & 4.59 & 3.64 & 4.91 & 5.20 & 4.49 \\
& Yes & 5.48 & 5.55 & 5.34 & 5.20 & 5.14 & 4.10 & 5.49 & 5.61 & 5.01 \\
Man5 & No & 5.31 & 5.28 & 5.10 & 5.10 & 5.01 & 3.95 & 5.32 & 5.40 & 4.85
\end{tabular}




\begin{tabular}{ccccccccccc} 
& Yes & 5.26 & 5.13 & 5.44 & 4.88 & 4.70 & 3.95 & 5.19 & 5.75 & 4.79 \\
Man6 & No & 3.53 & 3.00 & 3.00 & 3.00 & 3.33 & 3.03 & 3.33 & 3.00 & 3.30 \\
& Yes & 5.43 & 5.42 & 5.33 & 5.22 & 5.08 & 4.02 & 5.45 & 5.65 & 4.95 \\
Man7 & No & 4.72 & 4.82 & 4.65 & 4.62 & 4.40 & 3.60 & 4.90 & 4.00 & 4.36 \\
& Yes & 5.69 & 5.54 & 5.52 & 5.36 & 5.33 & 4.18 & 5.56 & 5.63 & 5.16 \\
Man8 & No & 5.21 & 5.13 & 5.03 & 4.97 & 4.87 & 3.81 & 5.22 & 5.38 & 4.73 \\
& Yes & 5.76 & 5.86 & 5.86 & 5.50 & 5.37 & 4.63 & 5.67 & 5.86 & 5.34 \\
\hline
\end{tabular}

Table 8

Relationship between application of general CSR management practices and level of ISR development. Test of difference in means: values of ANOVA test

\begin{tabular}{|c|c|c|c|c|c|c|c|c|c|c|}
\hline & & INHR & INREP & INOHS & ININTENV & INDEVEL & INBENEF & IDPROEMP & INUNREL & IISR \\
\hline \multirow[t]{2}{*}{ Man1 } & $\mathrm{F}$ & 40.395 & 27.951 & 13.635 & 18.963 & 16.875 & 6.713 & 34.225 & 7.284 & 27.904 \\
\hline & sign & .000 & .000 & .001 & .000 & .000 & .013 & .000 & 0.011 & .000 \\
\hline \multirow[t]{2}{*}{ Man2 } & F & 4.368 & 1.647 & 7.199 & 2.101 & 3.435 & 4.309 & 1.736 & 0.000 & 5.972 \\
\hline & sign & .043 & .207 & .011 & .155 & .071 & .044 & .195 & 0.984 & .019 \\
\hline \multirow[t]{2}{*}{ Man3 } & $\mathrm{F}$ & 3.570 & 2.907 & 7.241 & 1.585 & 2.802 & 1.442 & 2.101 & 1.629 & 4.243 \\
\hline & sign & .066 & .096 & .010 & .215 & .102 & .237 & .155 & 0.211 & .046 \\
\hline \multirow[t]{2}{*}{ Man4 } & $\mathrm{F}$ & 2.625 & 5.855 & 1.127 & .984 & 1.984 & 1.772 & 2.895 & 0.973 & 2.759 \\
\hline & sign & .113 & .0200 & .295 & .327 & .167 & .191 & .097 & 0.331 & .105 \\
\hline \multirow[t]{2}{*}{ Man5 } & $\mathrm{F}$ & .010 & .102 & .320 & .206 & .426 & .000 & .102 & 0.614 & .024 \\
\hline & sign & .919 & .751 & .575 & .652 & .518 & .994 & .751 & 0.439 & .878 \\
\hline \multirow[t]{2}{*}{ Man6 } & $\mathrm{F}$ & 11.053 & 14.778 & 7.965 & 10.562 & 6.607 & 2.496 & 15.201 & 16.238 & 9.948 \\
\hline & sign & .002 & .000 & .007 & .002 & .014 & .122 & .000 & 0.000 & .003 \\
\hline \multirow[t]{2}{*}{ Man7 } & $\mathrm{F}$ & 10.430 & 3.748 & 3.668 & 3.716 & 6.831 & 3.246 & 4.385 & 4.065 & 7.940 \\
\hline & sign & 0.002 & 0.060 & 0.062 & 0.061 & 0.013 & 0.079 & 0.043 & 0.053 & 0.007 \\
\hline \multirow[t]{2}{*}{ Man8 } & $\mathrm{F}$ & 1.588 & 2.153 & 1.834 & 1.019 & 1.013 & 3.702 & 1.081 & 1.031 & 2.394 \\
\hline & sign & .215 & .150 & .183 & .319 & .320 & .061 & .305 & .318 & .130 \\
\hline
\end{tabular}

Analysis of Hypothesis 3. Although the companies that have CSR areas or teams (Man4) present higher values across all dimensions of ISR, the difference was significant for only one dimension: INREP. Likewise, the relationship was not statistically significant in the case of the overall ISR indicator. These results invalidate Hypothesis 3: Having a team or area tasked with coordinating CSR issues is associated with a greater level of development of ISR.

Analysis of Hypothesis 4. The data reveal that there was no significant difference in the level of ISR development between companies that assign a full-time employee to CSR management (Man5) and those that do not. Not only that, but for several dimensions the value was somewhat higher in this second segment. Furthermore, in this management variable the values for the overall ISR indicator are almost the same value between the companies that apply it and those that do not. This invalidates Hypothesis 4: Appointing a full-time CSR manager is associated with a greater level of development of ISR. The validation of Hypothesis 2 and the invalidation of Hypotheses 5 and 6 suggests that involving managers in CSR issues is more effective in bringing about ISR development than in creating CSR areas or assigning employees to CSR management.

Analysis of Hypothesis 5. Although there was a correlation between the overall ISR index and having a code of ethics (Man2), this relationship was not replicated in every dimension of ISR. 
As can Table 4 shows, despite the companies that have a code of ethics (Man2) scoring higher on average than those that do not for almost every dimension of ISR, not all these differences are statistically significant. The differences recorded for the dimensions of "human rights," "health and safety," "professional development," and "provision of benefits" proved significant. But, in two of the dimensions in which externalities on employees have clear ethical implications ("reporting on issues that affect employees" and "protection of employment"), the differences are not statistically significant. These results only partially validate Hypothesis 3: Having a code of ethics is associated with a greater level of development of ISR.

Analysis of Hypothesis 6. In table 7 it can be observed that across all ISR dimensions the companies that publish reports achieve higher scores than the companies that do not publish them, but the difference is clearly significant only in the case of the occupational health and safety dimension (INSEGSAL ) and the general ISR index (table 8). In another two dimensions, the level of significance was less than 0.100 and greater than 0.050 , respectively: INHR and INREP. Therefore, the CSRI data invalidates Hypothesis 6: Periodically publishing a social or sustainability report is associated with a greater level of development of ISR. These results indicate that the publication of social or sustainability reports does not have a clear or direct relationship with ISR, and the publication of this type of report as an indicator of CSR should be regarded with caution.

Analysis of Hypothesis 7. Companies that possess their own foundation, or that participate in a foundation alongside other companies, score better in all dimensions, but the difference was not statistically significant in any one of the dimensions or in the overall ISR indicator.

Thus, the data invalidate Hypothesis 7: Possessing a foundation or participating alongside other companies in a foundation is associated with a greater level of development of ISR. This result is important because, in general, companies that have foundations seek to position themselves as socially responsible.

Analysis of Hypothesis 8. This result is important because, in general, companies that have foundations seek to position themselves as socially responsible. This relationship was found to be statistically significant in four of the dimensions and the overall ISR index, with significance levels lower than 0.050. In the other four dimensions the level of significance was somewhat weaker (between 0.050 and 0.100), but it should be borne in mind that the statistics were applied to a small sample. Therefore, Hypothesis 8 is validated: Membership of organizations dedicated to CSR promotion and training is associated with a greater level of development of ISR.

\section{Discussion and conclusions}

Although companies that adopt CSR apply, to a greater or lesser extent, the general CSR management practices referred to in this study, there is almost no research on their actual effect on internal social responsibility. Therefore, this study makes a novel contribution to research on CSR management, and particularly on ISR management.

Moreover, the finding that only some of these practices have an impact on the level of development of the ISR is a new one, since it is assumed in the business world that its application is conducive to higher levels of social responsibility and acts as an indicator of companies' socially responsible behavior. This is particularly true of the establishment of a CSR management area, the assignment of a full-time employee to CSR management, and the publication of a sustainability report.

In the case of general practices that positively correlate with ISR, questions emerge about how this relationship operates; in the case of general practices that do not correlate, new questions come up about why this does not happen and about what objectives are pursued through the application of these practices. 
The validation of Hypothesis 1 reinforces the findings of parts of the literature and implies that the extent to which companies apply CSR (at least internally) depends largely on whether CSR is included within strategic planning. This result is in line with the opinion of various authors who propose the need to incorporate CSR into strategic planning in order to assure uniform application throughout a company's operations, but especially in its HR strategy. This in turn presents an opportunity to investigate how the relationship between both variables operates in practice: Is one the cause of the other or do they feed into each other? Where should ISR implementation begin: in the general business strategy or the HR area strategy?

The answers to these questions can be of use to company managers and, to a greater extent, to HR professionals.

For its part, the validation of Hypothesis 2 reaffirms the role that leaders play with respect to the effective implementation of CSR, as the literature has found This result indicates that if the management team is involved in CSR issues, there is a greater probability that the company will act in a socially responsible way toward its employees. In addition, neither the creation of a CSR areas or management office (Hypothesis 3) nor the assignment of a full-time employee to CSR management (Hypothesis 4) condition a higher level of ISR, reinforcing the idea that CSR is a cross-cutting issue that is the responsibility of the entire organization. Placing CSR on the management team's agenda allows each manager to understand their part in its application and, in particular, in the application of ISR to employees in their area. The results of this study suggest another hypothesis: if managers of the different company areas are involved in CSR issues, they are more likely to adhere to and better apply the ISR policies proposed by the Human Resources area. The future analysis of this hypothesis implies new research questions that will surely require a combination of qualitative and quantitative studies.

The validation of Hypothesis 8 is a novel contribution to research on institutional practices that favor the incorporation of CSR by companies. Indeed, no research addressing this issue was identified, which suggests that if any does exist it is surely scarce. There are no scientifically validated findings on the reasons some companies participate as members of national or international organizations that promote CSR. In some cases, membership may be related to reputation-building goals, but in other cases the motivation may have more to do with access to training events, methodological materials, or consultation. This study shows that the member companies of DERES (the only organization in Uruguay dedicated solely to promoting CSR) are more advanced in the development and application of policies across all dimensions of ISR. Given that correlation is not causality, the question remains as to whether this result is explained because companies that are more advanced in ISR are more attracted to this type of organization or if greater development of ISR is a result of membership. The result of this study also raises new research questions related to the contribution of these organizations to the effective development of ISR: How can membership of these organizations influence greater development of ISR? Which of their activities are most influential? Does interaction between managers of member companies contribute to the exchange of good practices and a better understanding of the benefits of ISR?

To a greater or lesser degree, the different approaches to CSR recognize that ethics plays an important role in the socially responsible behavior of companies. Responsible management of externalities must be accompanied by the values and principles that guide responses to ethical dilemmas implicit in decision-making, as well as internal guidelines and norms that ensure the ethical behavior of company employees.

This is particularly important for socially responsible management of human resources. Because codes of ethics are formal tools that provide these guiding elements, it is reasonable to assume that companies that apply codes of ethics will be more advanced in the application of socially responsible HR policies. However, the result of this study only partially confirms this assumption. 
It is therefore worth asking why this is the case. The formulation of codes of ethics was originally proposed in the field of business ethics and not that of CSR, and so the partial validation of Hypothesis 5 raises the question of whether the use of these codes is the consequence of a broad approach to CSR or if, rather, it owes to a desire to incorporate ethical elements in decisionmaking processes and in the behavior of employees.

The publication of social or sustainability reports is one of the most visible of the general CSR management practices.

Many companies build their CSR reputation based on the publication and dissemination of these reports. Thus, many of the organizations that promote CSR publish manuals to guide their preparation (ILO, 2001; DERES, 2003; Acción Empresarial, 2001) or develop series of indicators for use as input for these reports (ETHOS , 2007; CERES, 2011; ACDE, 2019).

Some of these organizations also publish the reports of their member companies on their websites. Similarly, the widespread use of GRI indicators audited by renowned firms (Deloitte, Price Waterhouse Coopers, etc.) demonstrates the importance placed on these accountability tools. Against expectations, in this study the publication of social or sustainability reports was found not to correlate with the development of the ISR. If this result is confirmed in future studies, it will be necessary to inquire into the factors behind it. Is it possible that the publication of these reports is more widespread among companies that place greater importance on their external CSR? Which stakeholders are prioritized by the companies that publish them? To what extent do these reports cover the main dimensions of ISR? These are some of the questions that arise from the results obtained in this study.

The non-validation of Hypothesis 7 suggests that, contrary to what some authors maintain, foundations continue to be used as tools for corporate philanthropy or corporate social marketing, with some exceptions. The result of this study cast doubt on whether foundations are promoters of CSR within the companies behind them (Herlin \& Pedersen, 2012) or whether they create positive effects on corporate values (Bereskin \& Hsu, 2016). This result poses new research questions: What mission do companies that have adopted CSR assign to their foundations? How do these companies align the activities of their foundations with their ISR actions? Can foundations play a role in improving ISR?

This study has some strengths that are worth noting.

The first concerns the types of indicators used and who measures them. The literature on ISR focuses predominantly on the use of performance indicators--that is, indicators that measure the degree to which companies act on ISR.

On the other hand, the present study was based on management indicators that measure the existence of policies and their degree of application. While the former allow companies to monitor the perception of various stakeholders about ISR performance, the latter allow firms to evaluate the ways in which they manage employee-related externalities. Thus, the indicators employed in this study provide a complementary and useful perspective for management. On the other hand, it should be noted that in most studies the scoring of indicators is based on subjective elements: the opinions or satisfaction of employees, assessment by managers, or the judgement of experts. Moreover, this type of information is influenced by the differing interpretations, expectations, and experiences among those who do the evaluating. But in this study the indicators were measured based on information provided by the companies about the existence and application of policies. This information is less subjective and is surely more homogeneous in terms of the focus of measurement. 
The second strength refers to the classification of ISR practices across nine dimensions. Few studies of ISR cover the wide spectrum of externalities that this concept encompasses. The present study, however, was based on an extensive review of the literature, which allowed for a fairly exhaustive identification of these externalities. In addition, the database included indicators for eight of these nine dimensions, which allowed for effective measurement of ISR. The third strength lies in the fact that this study is easily replicable. Given that it involved the analysis of an existing database, and that similar databases must exist in other countries, it follows that this research can be replicated--although the indicators will not be exactly the same.

In turn, this study has some limitations that need to be made clear. The first is related to the definition and delimitation of the study universe: companies that are in the process of incorporating CSR into their management. On the one hand, there are no indicators that specify exactly whether a company meets this condition, and on the other, there are no databases that include this universe in its entirety. Thus, the universe of study is not precisely defined. The second limitation concerns the use of a non-probabilistic sample, made up of the companies that participated in the 2019 CSRI. In addition, the sample was small. The third limitation refers to the veracity of the information used, in that it was not audited. In this regard, it is worth noting the caveat of some authors, who have noted that the information that companies provide about their CSR may not be reliable (Whitehouse, 2006; Fenwick \& Bierema, 2008). The fourth limitation is that the indicators used were not constructed for the specific purposes of this study but for another end. The fifth and final limitation is that the study was applied in a single country so the results may be biased by various factors, including the dynamics of the internal market, the degree of professionalization of business management, the relative importance assigned to human resources, the power of unions, labor legislation, and public policies on labor relations.

\section{References}

Acción Empresarial (2001). Indicadores de Responsabilidad Social. Chile: Author.

ACDE (2019). $17^{a}$ edición IRSE. Indicadores de Responsabilidad Social Empresaria. https://www.acde.org.uy/irse. Consulted: 03/01/2020.

Achtenhagen, L., Melesko, S. \& Ots, M. (2018). Upholding the 4th estate-exploring the corporate governance of the media ownership form of business foundations. International

Journal of Media Management, 20(2), 129-150. https://doi.org/10.1080/14241277.2018.1482302

Aguilera, R., Ruth, V., Rupp, D., Williams, C. \& Ganapathi, J. (2007). Putting the S back in corporate social responsibility: A multi-level theory of social change in organizations. Academy of Management Review, 32(3), 836-863.

Aguinis, H. \& Glavas, A. (2013). What corporate environmental sustainability can do for industrial-organizational psychology. In A. H. Huffman and S. R. Kelin (Eds). Green organizations: Driving Change with I-O Psychology. New York: Routlege, pp. 379-392.

Albinger, H.S. \& Freeman, S. J. (2000). Corporate social performance and attractiveness as employer to different job seeking population. Journal of Business Ethics, 28: 243-253.

Ali, I, Rehman, K., Ali, S.I., Yousaf, J. \& Zia, M. (2010). Corporate social responsibility influences, employee commitment and organizational performance. African Journal of Business Management 4(12), 2796-2801.

Alves, R. \& Mundim, R. (2008). Responsabilidad Social Empresarial con el público interno: la percepción de los empleados de una empresa brasileña. Revista Forum Doctoral, 1, 2146.

Alzate, J. \& Orozco-Toro, J. (2015). Diseño y Responsabilidad Social Empresarial en la planeación estratégica de la marca. Revista KEPES, 12, 133-155. https://doi.org/10.17151/kepes.2015.12.12.7 
Askeroğlu, A. \& Bajar, Z. (2014). Contribution of Foundations to Reputation in Corporate Social Responsibility. International Journal of Economic Practices and Theories, 4(5), 718-725.

Barrena-Martínez, J., López, M. \& Romero, P. (2017). Socially responsible human resource policies and practices: Academic and professional validation. European Research on Management and Business Economics, 23, 55-61

Barrena-Martínez, J., López, M. \& Romero, P. (2018). The link between socially responsible human resource management and intellectual capital. Corporate Social Responsibility Environmental Management, 26(1), 71-81. https://doi.org/10.1002/csr.1658

Bereskin, F., \&. Hsu, P.H. (2016). Corporate Philanthropy and Innovation: The Case of the pharmaceutical Industry. Journal of Applied Corporate Finance, 28(2), 80-87.

Berniak-Woźny, J. \& Kwasek, A. (2020). Sustainability Reporting Practices in the Healthcare Products Sector - the Case of Europe and North America. Comparative Economic Research. Central and Eastern Europe, 23(2), 69-86 . http://dx.doi.org/10.18778/15082008.23 .13

Bohem, A. (2002 ). Corporate Social Responsibility: A Complementary Perspective of Community and Corporate Leaders. Business and Society Review, 107(2), 171-194. https://doi.org/10.1111/1467-8594.00131

Boiral, O., Heras Saizarbitoria, I., Brotherton, M.C. \& Bernard, J. (2019). Ethical Issues in the Assurance of Sustainability Reports: Perspectives from Assurance Providers. Journal of Business Ethics 159, 1111-1125. https://doi.org/10.1007/s10551-018-3840-3

Bowen (1953). Social responsibilities of the businessman. New York: Harper \& Row

Brammer, S., Millington, A. \& Rayton, B. (2007). The contribution of corporate social responsibility to organizational commitment. International Journal of Human Resource Management, 18, 1701-1719.

Buciuniene, I. \& Kazlauskaite, R. (2012). The linkage between HRM, CSR and performance outcomes. Baltic Journal of Management; 7(1), 5-24. https://doi:10.1108/17465261211195856

Calderón, R., Ferrero, I. \& Redín, D. (2012). Ethical codes and corporate responsibility of the most admired companies of the world: Toward a third generation ethics? Business and Politics, 14(4), 1-24. https://doi.org/10.1515/bap-2012-0044

Carroll, A. (1991). The pyramid of corporate social responsibility: Toward the moral management of organizational stakeholders. Business Horizons, 34, 39-48.

Carroll, A. (1999). Corporate Social Responsibility: Evolution of Definitional Construct. Business and Society, 38(3), 268-295.

Carroll, A. (2015). Corporate social responsibility: The centerpiece of competing and complementary frameworks. Organizational Dynamics, 44, 87-96.

CERES (2011). Guía CERES de indicadores sobre Responsabilidad Social Empresarial: Ecuador: Author.

Clemente, A., Ribeiro, F, de Paula, O. \& Mendonca, N. (2019). Analysis of contents of annual sustainability reports of industrial companies participating in the Sustainability Index of the Brazilian Stock Exchange. Rev. Adm. UFSM, Santa Maria, 12, Edição Especial, 1211-1226. DOI: 10.59021983465937995.

Collier, J. \& Esteban, R. (2007). Corporate social responsibility and employee commitment. Business Ethics: A European Review, 16(1), 19-33.

Dahlsrud, A. (2008). How Corporate Social Responsibility is defined: An Analysis of 37 Definitions. Corporate Social Responsibility and Environmental Management, 15, 1-13.

Davis, K. \& Blomstrom, R. (1966). Business and its environment. New York: McGraw--Hill. 
De Paula, Da Silva \& Tscha (2011). A Percepção dos Profissionais Atuantes em Recursos Humanos sobre a Responsabilidade Social Empresarial. III Encontro de Gestao de Pessoas e Relacoes de Trabalho 20-22 de Noviembre de 2011.

Delfgaauw, T. (2000). Reporting on Sustainable Development: A Preparer's View. Auditing: $a$ Journal of Practice \& Theory, 19 supplement, 67-74.

DERES (2001). Manual de Primeros Pasos. Responsabilidad Social Empresaria. Montevideo: Author.

DERES (2003). Manual para la preparación e implementación del Balance Social en Uruguay. Montevideo: Author.

DERES (2015). Las mejores prácticas de RSE. Uruguay: Author. https://deres.org.uy/bibliotecavirtual/documentos/. Consulted: 08/10/2020.

Ena B. \& Delgado S. (2012). Recursos Humanos y Responsabilidad Social Corporativa. Paraninfo: Spain.

Epstein, E. M. (1987). The corporate social policy process: Beyond business ethics, corporate social responsibility, and corporate social responsiveness. California Management Review, 29, 99-114.

ETHOS (2007). Indicadores ETHOS de Responsabilidade Social. Brazil: Author.

Fenwick, T. \& Bierema, L. (2008). Corporate social responsibility: issues for human resource development professionals. International Journal of Training and Development 12(1), 24-35.

Fernandez-Feijoo, B., Romero, S. \& Ruiz, S. (2014 ). Effect of Stakeholders' Pressure on Transparency of Sustainability Reports within the GRI Framework. Journal of Business Ethics, 122, 53-63. DOI 10.1007/s10551-013-1748-5

Fernandez-Gago, R. \& Martínez-Campillo, A. (2008). Naturaleza estratégica de la responsabilidad social. Journal of Globalization, Competitiveness \& Governability, 2(2), 116-125. https://doi:10.3232/GCG.200

Ferreira, P. \& Real de Oliveira, E. (2014). Does corporate social responsibility impact on employee engagement? Journal of Workplace Learning, 26(3/4), 232-247.

Fitch, G. (1976). Achieving corporate social responsibility. Academy of Management Review, 1, 38-46.

Frederick, W., Post, J. \& Davis, K. (1992). Business and Society. Corporate Strategy, Public Policy, Ethics. London: McGraw-Hill.

Freeman, E. (1983). Stockholders and Stakeholders: A New Perspective on Corporate Governance. California Management Review; 25(3), 88-106.

Furlotti1, K., Mazza, T., Tibiletti, V., \& Triani, S. (2017). Women in top positions on boards of directors: Gender policies disclosed in Italian sustainability reporting. Corporate Social Responsibility and Environmental Management, 26, 57-70. https://doi.org/10.1002/csr.1657

Gaete, R. (2010). Discursos de gestión de recursos humanos presentes en Iniciativas y Normas de responsabilidad social. Revista Gaceta Laboral, 16(1), $41-62$.

Gallego, I. (2006). The Use of Economic, Social and Environmental Indicators as a Measure of Sustainable Development in Spain. Corporate Social Responsibility and Environmental Management, 13, 78-97. DOI: 10.1002/csr.094

García \& Duque (2012). Gestión humana y responsabilidad social empresarial: un enfoque estratégico para la vinculación de prácticas responsables a las organizaciones. Libre Empresa, 9(1), 13-37.

García, M., Azuero, A. \& Peláez, J. (2013). Prácticas de Responsabilidad Social Empresarial desde las áreas funcionales de Gestión Humana: análisis de resultados en cuatro empresas 
del suroccidente colombiano. INNOVAR. Revista de Ciencias Administrativas y Sociales, 23(49), 83-100

Garriga, E. \& Melé, D. (2004). Corporate social responsibility theories: Mapping the territory. Journal of Business Ethics, 53: 51-71.

Global Reporting Initiative (2006). Guía para la elaboración de Memorias de Sostenibilidad. Amsterdam: Author.

Godiwalla, Y. (2012). Business Ethics And Social Responsibility Strategies For Foreign Subsidiaries. Journal of Diversity Management, 7 (1), 1-10.

Gracia, G. \& Melendez, J. (2019). Retos de la planificación estratégica en la responsabilidad social corporativa: un caso del sector petrolero. Revista Espacios, 40(27), 2-10.

Guarnieri, R. \& Kao, T. (2008). Leadership and CSR--a perfect match: how top companies for leaders utilize CSR as a competitive advantage. People \& Strategy 31(3), 34-41.

Guzmán, M (2016). Dimensión Interna de la Responsabilidad Social Empresaria desde la óptica de la Gestión de Recursos Humanos. Saber, Universidad de Oriente, Venezuela, 28 (4), 794-805.

Herlin, J. \& Pedersen, J. (2013). Corporate Foundations: Catalysts of NGO-Business Partnerships? The Journal of Corporate Citizenship, 50, 58-90.

Herrera, J. \& de las Heras, C. (2020). Corporate Social Responsibility and Human Resource Management: Towards Sustainable. Sustainability, 12, 841, 1-24. http://dx.doi.org/10.3390/su12030841.

Hussey, D., Kirsop, P. \& Meissen, R. (2001). Global Reporting Initiative Guidelines: An Evaluation of Sustainable Development Metrics for Industry. Environmental Quality Management, 11(1), 1-20. https://doi.org/10.1002/tqem.1200

IARSE. (2005). Manual de Primeros pasos en RSE. Argentina: Author.

Isenmann, R., Bey, C. \& Welter, M. (2007). Online Reporting for Sustainability Issues. Business Strategy and the Environment, 16, 487-501. DOI: 10.1002/bse.597

ISO (2011), Guía de Responsabilidad Social (ISO 26000:2012, IDT). Montevideo: UNIT.

James, L. (2012). Sustainable Corporate Social Responsibility - An analysis of 50 definitions for a period of 2000-2011. International Journal of Multidisciplinary Research, 2(10), 169193.

Jaramillo, O. (2011). La dimensión interna de la responsabilidad social en las micro, pequeñas y medianas empresas del programa expopyme de la Universidad del Norte. Pensamiento y Gestión, 31, 167-195.

Johansen, T.R. (2010). Employees, Non-financial Reports and Institutional Arrangements: A Study of Accounts in the Workplace. European Accounting Review 19(1), 97-130. DOI: $10.1080 / 09638180902989392$

Johnson, H. (1971). Business in contemporary society: Framework and issues. Belmont, CA: Wadsworth.

Joiner, B. \& Payne, D. (2002). Evolution and Implementation: A Study of Values, Business Ethics and Corporate Social Responsibility. Journal of Business Ethics, 41(4), 297-311.

Jones, T. (1980, Spring). Corporate social responsibility revisited, redefined. California Management Review, 2(3) 59-67.

Khoury G., Rostami J. \& Turnbull, P. (1999). Corporate Social Responsibility: Turning Words into Action. Conference Board of Canada: Ottawa.

Kok, P., Van der Wiele, T., McKenna, R. \& Brown, A. (2001). Corporate Social Responsibility Audit within a Quality Management Framework. Journal of Business Ethics, 31(4), 285297. 
Kolk, A. (2004). A decade of sustainability reporting: developments and significance. Int. J. Environment and Sustainable Development, 3(1), 51-64.

Lee, D., Yu, G., Sirgy, M., Singhapakdi, A. \& Lucianetti, L. (2018). The Effects of Explicit and Implicit Ethics Institutionalization on Employee Life Satisfaction and Happiness: The Mediating Effects of Employee Experiences in Work Life and Moderating Effects of Work-Family Life Conflict. Journal of Business Ethics, 147:855-874. https://doi.org/10.1007/s10551-015-2984-7

Licandro, O., Alvarado-Peña, L., Sansores, E. \& Navarrete, J. (2019). Responsabilidad Social Empresaria: Hacia la conformación de una tipología de definiciones. Revista Venezolana de Gerencia, 24(85), 281-299.

Lichtenstein, D., Drumwright, M. \& Braig, B. (2004), The Effect of Corporate Social Responsibility on Customer Donations to Corporate-Supported Nonprofits. Journal of Marketing, 68(4), 16-32.

Logsdon, J. \& Wood, D. (2005). Global Business Citizenship and Voluntary Codes of Ethical Conduct. Journal of Business Ethics, 59, 55-67. https://doi.org/10,1007/s10551-005$\underline{3411-2}$

López, A., Ojeda, F. \& Ríos, M. (2017) La responsabilidad social empresarial desde la percepción del capital humano. Estudio de un caso. Revista de Contabilidad - Spanish Accounting Review 20(1), 36-46.

Low, M.P. (2016). Corporate Social Responsibility and the Evolution of Internal Corporate Social Responsibility in $21^{\text {st }}$ Century. Asian Journal of Social Science and Management Studies, 3(1), 56-74.

Malhotra, N. \& Miller, G. (1999). Social Responsibility and the Marketing Educator: A Focus on Stakeholders, Ethical Theories, and Related Codes of Ethics. Journal of Business Ethics, 19, 211-224.

Manetti, G. \& Becatti, L. (2008). Assurance Services for Sustainability Reports: Standards and Empirical Evidence. Journal of Business Ethics, 87, 289-298. DOI 10.1007/s10551-0089809-x

Manetti, G. (2011). The Quality of Stakeholder Engagement in Sustainability Reporting: Empirical Evidence and Critical Points. Corporate Social Responsibility and Environmental Management, 18, 110-122. DOI: 10.1002/csr.255

Marinescu, A.O. (2020). Analysis on the Compliance of Sustainability Reports of Romanian Companies with GRI Conceptual Framework, Audit Financiar, 18(2), 361-375. DOI: 10.20869/AUDITF/2020/158/011

McGuire, Joseph (1963), Business and society. New York: McGraw-Hill.

McWilliams, A., Siegel, D. \& Wright, P. (2006). Corporate Social Responsibility: Strategic Implications. Journal of Management Studies 43(1), 1-19. https://doi.org/10.1111/j.1467-6486.2006.00580.x

Minciullo, M. \& Pedrini, M. (2015). Knowledge Transfer between For-Profit Corporations and Their Corporate Foundations. Which methods are effective? Nonprofit Management \& Leadership, 25(3) 215-234. DOI: 10.1002/nml.21125

Monfort, A. \& Villagra, N. (2016). Corporate Social Responsibility and Corporate Foundations in building responsible brands. El profesional de la información, 25, 767-777.

Morhardt, E., Baird, S. \& Freeman, K. (2002). Scoring Environmental and Sustainability Reports using GRI 2000, ISO 14031 and other criteria. Corporate Social Responsibility and Environmental Management, 9, 215-233. DOI: 10.1002/csr.26 
Murray, K. \& Montanari, J. (1986). Strategic Management of the Socially Responsible Firm: Integrating Management and Marketing Theory. Academy of Management Review, 11 (4) 815-827 http://dx.doi:10.2307/258399

Murray, K. \& Vogel, C.M. (1997). Using a Hierarchy-of-Effects Approach to Gauge the Effectiveness of Corporate Social Responsibility to Generate Goodwill Toward Firm: Financial versus Nonfinancial Impact. Journal of Business Research 38, 141-159.

Nilipour, A., De Silva, T.A. \& Xuedong, L. (2020). The Readability of Sustainability Reporting in New Zealand over time The Readability of Sustainability Reporting in New Zealand over time. $A A B F, 14(3), 87-107$.

Obeidat, B. (2016). Exploring the Relationship between Corporate Social Responsibility, Employee Engagement, and Organizational Performance: The Case of Jordanian Mobile Telecommunication Companies. Int. J. Communications, Network and System Sciences, 9, 361-386. http://dx.doi.org/10.4236/ijens.2016.99032

Ofenhejm, A. \& Queiroz, A. (2019). Sustainable human resource management and social and environmental responsibility: An agenda for debate. Revista de Administração de Empresas Revista de Administração de Empresas, 59(5), 353-364. http://dx.doi.org/10.1590/S0034-759020190505

OIT (2001). Manual de Balance Social. Versión actualizada. Medellín: Author.

Painter-Morland, M. (2006). Triple bottom-line reporting as social grammar: integrating corporate social responsibility and corporate codes of conduct. Business Ethics: A European Review, 15(4), 352-364.

Perrini, F. (2005). Building a European Portrait of Corporate Social Responsibility Reporting. European Management Journal, 23(6), 611-627.

Porter, M. \& Kramer, M. (2007). Strategy and Society: The Link Between Competitive Advantage and Corporate Social Responsibility. Harvard Business Review 84, 78-92.

Reder, A. (1994). In Pursuit of Principle and Profit: Business Success through Social Responsibility. New York: Putnam.

Rudnika, A. (2017). Codes of conduct and codes of ethics as tools used to support the idea of Social Responsibility in supply chains. Research papers of Wroclaw University of Economics, 464, 91-100. http://dx.doi.org/10.15611/pn.2017.464.08

Sánchez-Hernández, M. I., Gallardo-Vázquez, D., Barcik, A., \& Dziwiński, P. (2016). The effect of the internal side of social responsibility on firm competitive success in the business services industry. Sustainability, 8(2), 179.

Sarmiento del Valle (2010). Gestión estratégica: clave para la responsabilidad social de las empresas. Dimensión Empresarial, 8(2), 24-37.

Simnet, R., Vanstraelen, A \& Chua, W. (2009). Assurance on Sustainability Reports: An International Comparison. The accounting Review, 84(3), 937-967. DOI: 10.2308/accr.2009.84.3.937

Smeuninx, N., De Clerck, B. \& Aerts, W. (2020). Measuring the Readability of Sustainability Reports: A Corpus-Based Analysis Through Standard Formulae and NLP. International Journal of Business Communication 57(1) 52-85. doi/10.1177/2329488416675456

Social Accountability International (2008). Responsabilidad Social 8000. SA 8000. http://www.mitramiss.gob.es/ficheros/rse/documentos/monitoreo/SA8000.pdf. Consulted: 03/15/2020.

Steiner, G. (1971). Business and society. New York: Random House.

Thomsen, S., Poulsen, T., Børsting, C. \& Kuhn, J. (2018). Industrial foundations as long term owners. Corporate Governance: An International Review, 26, 180-196. https://doi.org/10.1111/corg.12236 
Turker, D. (2009a). Measuring Corporate social responsibility: A scale development study. Journal of Business Ethics, 85: 411-427.

Turker, D. (2009b). How Corporate Social Responsibility Influences Organizational Commitment. Journal of Business Ethics,89,189-204

Valentine, S. y Fleischman, G. (2008). Ethics Programs, Perceived Corporate Social Responsibility and Job Satisfaction. Journal of Business Ethics, 77, 159-172. http://dx.doi.org/10.1007/s10551-006-9306-z

Vittel, S., Paolillo, J. \& Thomas, J. (2003). The perceived role of Ethics and Social Responsibility: a study of Marketing Professionals. Business Ethics Quarterly, 13(1), 63-86.

Voegtlin, C., \& Greenwood, M. (2016). Corporate social responsibility and human resource management: A systematic review and conceptual analysis. Human Resource Management Review, 26(3), 181-197.

Waldman, D., Siegel, D. \& Javida, M. (2004). Components of CEO Transformational Leadership and Corporate Social Responsibility. Journal of Management Studies, 43(8), 1703-1725. http://dx.doi.org/10.1111/j.1467-6486.2006.00642.x

Wallage, P. (2000). Assurance on Sustainability Reporting: An Auditor's View. Auditing: A Journal of Practice \& Theory, 19 Supplement, 54-65.

Westhues, M. \& Einwiller, S. (2006). Corporate Foundations: Their Role for Corporate Social Responsibility. Corporate Reputation Review, 9(2), 144-153.

Willis, A. (2003). The Role of the Global Reporting Initiative's Sustainability Reporting Guidelines in the Social Screening of Investments. Journal of Business Ethics 43, 233237. https://doi.org/10.1023/A:1022958618391

Zaman, R. \& Nadeem, M. (2019). Linking Corporate Social Responsibility (CSR) and Affective Organizational Commitment: Role of CSR Strategic Importance and Organizational Identification. Pakistan Journal of Commerce and Social Sciences, 13(3), 704-726.

Zenisek, T. (1979). Corporate social responsibility: A conceptualization based on organizational literature. Academy of Management Review, 4, 359-368. 